\title{
The International Urogynecological Association/ International Continence Society classification of complications of prosthesis and graft insertion: Pros and cons and a review of the literature
}

\author{
Murat Yassa, (D) Ozan Doğan \\ Clinic of Obstetrics and Gynecology, Şişli Hamidiye Etfal Training and Research Hospital, İstanbul, Turkey
}

\begin{abstract}
International Urogynecological Association (IUGA) and the International Continence Society (ICS) and the Joint IUGA/ICS Working Group on Complications Terminology formulated a standardized terminology and classification of complications related to the use of prosthesis in female pelvic floor surgeries. It was mainly purposed to globally standardize the complications and related definitions in order to obtain factual rates and to enable comparisons and surgical audits. Although this unique classification has frequently been cited in the literature, some concerns have been raised against its complexity of use and inter- and intraobserver variability. This review aimed to discuss the rationale behind the IUGA/ICS complication classification system, underline the opposing views, and provide the Turkish version of an online calculator facilitating the universal coding to increase the utility. (J Turk Ger Gynecol Assoc 2020; 21: 57-61)
\end{abstract}

Keywords: Calculator, complications terminology, female pelvic floor surgeries, graft, prosthesis

Received: 27 February, 2019 Accepted: 10 June, 2019

\section{Introduction}

The International Urogynecological Association (IUGA) and the International Continence Society (ICS) and the Joint IUGA/ICS Working Group on Complications Terminology formulated a standardized terminology and classification of complications related to the use of prosthesis in female pelvic floor surgeries (1). This classification system is the first attempt to systematically classify the related complications. It was mainly purposed to globally standardize the complications and related definitions in order to obtain factual rates and to enable comparisons and surgical audits. Although this unique classification currently has over 150 citations (https:// citations.springer.com/item?doi $=10.1007 / \mathrm{s} 00192-010-1324-9$, data received at 11/02/2019), some concerns has been raised against its complexity of use and inter- and intraobserver variability $(2,3)$. This non-systematic review aimed to discuss the rationale behind the IUGA/ICS complication classification system, underline the opposing views, and provide the Turkish version of an online calculator facilitating the universal coding to increase the utility (Supplement).

\section{Rationale}

Mid-urethral sling is the gold standard and the most common surgical procedure to treat stress urinary incontinence (SUI) with a proven superiority over other surgical procedures (4). Although mid-urethral slings exhibit a good safety and effectivity profile, a safety concern has been raised globally against the vaginal use of mesh, particularly to treat pelvic organ prolapse. The use of synthetic mesh has statistically decreased between 2011 and 2013 after the second United States Food and Drug 
Administration Public Health Notification; however, the number of mesh revision surgeries increased by almost three-fold from 2007 to 2013 (5).

A recent meta-analysis consisting of 28 randomized controlled trials (RCTs) and 15,855 patients showed that patients who received mid-urethral sling had higher overall and objective cure rates than those who underwent Burch colposuspension (4). The latest Cochrane systematic review assessing midurethral slings for SUI determined that major complications such as nerve, bowel or major vascular injuries, pelvic haematoma, necrotizing fasciitis, ischiorectal abscess, and death were found to be uncommon in mid-urethral slings (6). Bladder perforation, reoperation, urinary retention, pelvic haematoma, infection, vaginal tape erosion/extrusion and groin pain occurred in $3.9 \%, 2.4 \%, 1.6 \%, 1.9 \%, 0.7 \%, 1.5 \%$ and $0.4 \%$ of women underwent to retropubic tape procedure, respectively. Those rates were $0.4 \%, 2.2 \%, 0.5 \%, 0.5 \%, 0.6 \%, 0.4 \%$, and $1.6 \%$ for transobturator tapes (6). Another large population-based retrospective series consisting of 95,057 women was recently published (7). Women who had their first mid-urethral sling procedure to treat SUI were included and followed for 5.5 (interquartile range, 3.2-7.5) years. They found that the rate of mesh sling removal was $1.4 \%$ at 1 year, $2.7 \%$ at 5 years, and $3.3 \%$ at 9 years. The rate of all reoperations was found as $2.6 \%$, $5.5 \%$, and $6.9 \%$, at 1, 5, and 9 years, respectively. By contrast, the recent largest study of vaginal mesh in the treatment of SUI including 92,246 women, revealed that almost one out of every ten patients experienced a complication within 5 years of the initial mesh surgery (8). Among those, rate of complications have risen during the surgery and in the first month were found as $2.4 \%$ and $1.7 \%$, respectively.

It has been argued that RCTs designed for long-term follow-up possess limited information about whether there was a hidden cache of serious adverse effects that might have been set against the benefits of curing incontinence (6). Many reporting systems belonging to the major registries were characterized by passive surveillance systems limited by the inclusion of the potential submission of incomplete or inaccurate data, underreporting of events, lack of denominator data, and the lack of report timeliness ) (6).

Due to the inconsistent and increasing reports of complication rates, the IUGA and ICS proposed a well-detailed but inclusive classification system of complications related to the use of all types of prostheses including meshes, implants, tapes, and grafts in female pelvic floor surgery (1).

\section{Classification system and coding}

The IUGA/ICS system was developed to cover all possible physical complications, including trocar-related insertion complications and healing abnormalities. The classification system depends on three main factors: Category (numeric) and division (letter), Time (numeric + letter), and Site (numeric + letter), respectively, and all together, this is called the cheque truncation system (CTS). "Category" refers to the general description of the complication such as the degree or extent of erosion (according to former usage), affected site or the condition of the patient. "Division" refers to four common major complication types: A-Asymptomatic, B-Symptomatic, C-Infection, D-Abscess. "Time" describes the duration between the surgery and clinically diagnosed complication. "Site" describes the localization of the complication. One can obtain a code of 3 letters and 3 numerals after classification (e.g. 2B/T3/ S1) (Figure 1). The only sub-group reflects "pain" according to the vaginal examination and/or anamnesis. Pain adds a lower case next to the division (e.g. 2Bc/T3/S1, if a patient expresses pain during sexual intercourse).

One of the main prominent features in the newly proposed joint terminology is that the term erosion is not favoured. Mesh inherently interacts with adjacent tissue. Therefore, it is replaced by terms of vaginal epithelium separation, exposure, extrusion, contraction, prominence, and sinus tract formation. Additional new terms include compromise, perforation, and dehiscence (1). Although exposure can simply be described as visible or palpable mesh through separated epithelium (mainly the vaginal wall) in the early period, extrusion represents a subsequent delayed process by which mesh protrudes gradually out of a body structure or adjacent tissue such as the vagina, bladder, and urethra. Perforation frequently refers to perioperative events. In addition, the classification system has dynamic characteristics. Naturally, multiple complications may occur in the same patient at the same time or over a period of time and all should be reported separately (1).

The boundaries of the CTS system include not covering the urinary tract infections, functional issues (e.g. voiding dysfunction), intraperitoneal adhesions and prion or viral infection of a xenograft. Secondly, recurrence is not situated in the CTS system because recurrence is not counted as a complication. Those exclusions are probably postulated to be not directly related to the insertion of prosthesis. Lastly, complications linked to the bulking agents are also not included.

\section{Literature and opposing views}

Petri and Ashok assessed the applicability of the IUGA-ICS classification by retrospectively analysing 359 patients who underwent surgical management due to a complication directly related to insertion of a synthetic sling and classified each complication according to the new IUGA-ICS classification using an online calculator (https://www.ics.org/ complication). Although they found that the new classification 


\begin{tabular}{|c|c|c|c|c|c|c|}
\hline \multicolumn{7}{|c|}{ CATEGORY } \\
\hline & \multirow{2}{*}{\multicolumn{2}{|c|}{$\begin{array}{l}\text { General Description } \\
\text { Vaginal: no epithelial separation } \\
\text { Include prominence (e.g. due to wrinkling or folding), } \\
\text { mesh fibre palpation or contraction (shrinkage) }\end{array}$}} & A (Asymptomatic) & \multirow{2}{*}{$\begin{array}{l}\text { B (Symptomatic) } \\
\text { 1B: Symptomatic e.g. unusual } \\
\text { discomfort / pain; dyspareunia } \\
\text { (either partner); bleeding }\end{array}$} & \multicolumn{2}{|c|}{ C (Infection) D (Abscess) } \\
\hline 1 & & & $\begin{array}{l}\text { 1A: Abnormal prosthesis or graft } \\
\text { finding on clinical examination }\end{array}$ & & \multicolumn{2}{|c|}{$\begin{array}{l}\text { 1C: Infection } \quad 1 D=\text { Abscess } \\
\text { (suspected } \\
\text { or actual) }\end{array}$} \\
\hline 2 & \multicolumn{2}{|c|}{ Vaginal: smaller $\leq 1 \mathrm{~cm}$ exposure } & 2A: Asymptomatic & 2B: Symptomatic & \multicolumn{2}{|l|}{ 2C: Infection } \\
\hline 3 & \multicolumn{2}{|c|}{ Vaginal: larger $>1 \mathrm{~cm}$ exposure, or any extrusion } & $\begin{array}{l}3 A \text { : Asymptomatic } \\
1-3 A a \text { if no prosthesis or graft } \\
\text { related pain }\end{array}$ & $\begin{array}{l}3 B \text { : Symptomatic } \\
1-3 B(b-\theta) \text { if prosthesis or graft } \\
\text { related pain }\end{array}$ & \multicolumn{2}{|c|}{$\begin{array}{l}3 C \text { : Infection } 3 D=\text { Abscess } \\
1-3 C / 1-3 D(b-\theta) \text { if prosthesis } \\
\text { or graft related pain }\end{array}$} \\
\hline 4 & \multicolumn{2}{|c|}{$\begin{array}{l}\text { Urinary Tract: compromise or perforation } \\
\text { Including prosthesis (graft) perforation, fistula and calculus }\end{array}$} & $\begin{array}{l}\text { 4A: Small intraoperative defect } \\
\text { e.g. bladder perforation }\end{array}$ & $\begin{array}{l}\text { 4B: Other lower urinary tract } \\
\text { complication or urinary retention }\end{array}$ & \multicolumn{2}{|c|}{$\begin{array}{l}\text { 4C: Ureteric or upper } \\
\text { urinary tract complication }\end{array}$} \\
\hline 5 & \multicolumn{2}{|c|}{$\begin{array}{l}\text { Rectal or Bowel: compromise or perforation } \\
\text { including prosthesis (graft) perforation and fistula }\end{array}$} & $\begin{array}{l}\text { 5A: Small intraoperative defect } \\
\text { (rectal or bowel) }\end{array}$ & 5B: Rectal injury or compromise & \multicolumn{2}{|c|}{$\begin{array}{l}\text { 5C: Small or Large bowel injury } \\
\text { or compromise } 5 D=\text { Abscess }\end{array}$} \\
\hline 6 & \multicolumn{2}{|c|}{$\begin{array}{l}\text { Skin and / or musculoskeletal: complications } \\
\text { including discharge pain lump or sinus tract formation }\end{array}$} & $\begin{array}{l}\text { 6A: Asymptomatic, abnormal } \\
\text { finding on clinical examination }\end{array}$ & $\begin{array}{l}\text { 6B: Symptomatic e.g. discharge, } \\
\text { pain or lump }\end{array}$ & \multicolumn{2}{|c|}{$\begin{array}{l}\text { 6C: Infection e.g. sinus tract } \\
\text { formation } \quad 6 D=\text { Abscess }\end{array}$} \\
\hline 7 & \multicolumn{2}{|c|}{$\begin{array}{l}\text { Patient: compromise } \\
\text { including hematoma or systemic compromise }\end{array}$} & $\begin{array}{l}\text { 7A: Bleeding complication } \\
\text { including haematoma }\end{array}$ & $\begin{array}{l}\text { 7B: Major degree of resuscitation } \\
\text { or intensive care* }\end{array}$ & \multicolumn{2}{|c|}{$\begin{array}{l}\text { 7C: Mortality * } \\
\text { *(additional complication } \\
\text { - no site applicable - S 0) }\end{array}$} \\
\hline \multicolumn{7}{|c|}{ TIME (clinically diagnosed) } \\
\hline \multicolumn{3}{|c|}{ T1: Intraoperative to 48 hours } & \multicolumn{2}{|c|}{ T3: 2 months to 12 months } & \multicolumn{2}{|c|}{ T4: over 12 months } \\
\hline \multicolumn{7}{|c|}{ SITE } \\
\hline \multicolumn{2}{|c|}{$\begin{array}{l}\text { S1: Vaginal: } \\
\text { area of suture line }\end{array}$} & $\begin{array}{l}\text { S2: Vaginal: away from } \\
\text { from area of suture line }\end{array}$ & $\begin{array}{l}\text { S3: Trocar passage } \\
\text { Exception: Intra-abdominal (S5) }\end{array}$ & $\begin{array}{l}\text { S4: other skin or } \\
\text { musculoskeletal site }\end{array}$ & \multicolumn{2}{|c|}{ S5: Intra-abdominal } \\
\hline N.B. & \multicolumn{6}{|c|}{$\begin{array}{l}\text { 1. Multiple complications may occur in the same patient. There may be early and late complications in the } \\
\text { same patient. i.e. All complications to be listed. Tables of complications may often be procedure specific. } \\
\text { 2. The highest final category for any single complication should be used if there is a change over time. (patient } 888 \text { ) } \\
\text { 3. Urinary tract infections and functional issues (apart from } 4 \mathrm{~B} \text { ) have not been included. }\end{array}$} \\
\hline & & & & CODE & $-\mathbf{T}$ & \\
\hline
\end{tabular}

Figure 1. The IUGA/ICS classification system of complications of prosthesis and graft insertion 1 IUGA: International Urogynecological Association, ICS: International Continence Society

system had good general applicability, it was inadequate to classify overactive bladder (OAB), which was accounted as the most common complication with a rate of $54 \%(n=193)$. Lower urinary tract obstruction requiring resection or cutting the sling was the second most common complication at 48\% $(n=174)$. This complication was classified as 4B; however, the authors could not state the "Site". Except those two, the CTS system was beneficial in classifying most of the rare and common complications. Along with including OAB and subclassifying 4B, Petri and Ashok also recommended some other rare complications to be labelled as miscellaneous such as dyspareunia of the partner, urine loss during intercourse, and foreign body sensation in the vagina.

In 2015, Miklos et al. (9) analyzed mesh complications among women who had undergone pelvic floor reconstructive surgery with mesh including sub-urethral mesh slings, transvaginal synthetic mesh, and sacrocolpopexy in their multi-centre retrospective study. A total of 445 patients were included from three tertiary urogynecological referral centers. Unlike Petri and Ashok, all of the complications that mainly consisted of complicated and often recurrent cases were possible to be classified using the IUGA-ICS classification system in their study.

Tunitsky et al. (2) retrospectively analyzed 1236 patients and identified 133 eligible patients presenting after pelvic organ prolapse or incontinence surgery with 195 mesh-related complications in their study to assess the interrater reliability of the IUGA-ICS classification. The complications were classified by 2 independent reviewers using the ICS/IUGA classification system. They observed low agreement at $44.09 \%$ on vaginal complications (categories of 1A-3D), high agreement on urologic (96.1\%, categories of 4A-4C) and bowel complications (100\%, categories of $5 \mathrm{~A}-5 \mathrm{C}$ ). The authors claimed that $2.2 \%$ of the complications could not be classified into any organ/ severity categories, and the "Site" of the complications could not be located in 38\% due to the lack of clarity of the IUGA-ICS classification. Interestingly, they also observed low agreement on "complication time" and "complication site" between the two independent reviewers with $47.6 \%$ and $29.7 \%$, respectively. Tunitsky et al. (2) suggested that complications might be classified by symptom and intervention rather than the physical findings. For example, they argued that Category 5, which was 
designated for bowel complications, did not cover defecatory dysfunction. Although that proposal would probably increase the complexity of the classification system, we believe that Tunitsky et al. (2) might have a point, particularly in pelvic organ prolapse surgeries, but not necessarily in anti-incontinence procedures $(10,11)$. We were able to explain all complications using the CTS system after insertion of old- and new-generation mid-urethral slings to treat USI.

The feasibility and the difference of the complication system between prolapse and anti-incontinence surgeries was assessed in a single-centre retrospective study that used a wide range of surgical kits (12). The most frequent complications varied with the type of the surgery, which were found to be bladder outlet obstruction for vaginal sling-plasty, and pain for prolapse surgery. The affected site also differed between them, but the time remained statistically similar. The authors commented that using the CTS code might provide a quick overview of patients' major findings in a more general way; however, the complication classification system needed to evolve in a such way that it covered functional disorders (e.g. urgency, constipation, and dyschezia) given that $17.32 \%$ $(n=31 / 179)$ of the patients presented with only functional problems in their study.

Following the assertion of poor interrater reliability of the IUGA-ICS classification, Gowda et al. (3) had similar results in their study that stratified interobserver reliability by stage of training. It should be noted that the authors stated their study was underpowered and had sampling bias. As a response to studies showing poor interrater and interobserver reliability, the original authors ran the hypothesis that the poor reproducibility was because of imperfect study designs and that the reliability could be strengthened through optimized training prior to use of the CTS IGAU/ICS complication classification system. Haylen et al. (13) achieved excellent interobserver reliability (93\%) with no significant differences among 39 respondents after giving structured instructions supported by photos and quizzes, even though the participants were under time pressure and had no access to the online calculator.

Batalden et al. (14) assessed the retrospective applicability of the IUGA/ICS classification system. The authors only included complications with mesh erosion and the newly expanded definitions consisting of contraction, prominence, separation, exposure, extrusion, perforation, dehiscence, and sinus tract formation. They observed that the classification did not predict the treatment or outcome of the complication, and $30 \%$ of the mesh erosions could not be retrospectively coded with the CTS system. However, it was mainly due to missing information that did not exist in the clinical documentation or operative reports. Bontje et al. (15) specifically assessed the complications of patients who consecutively underwent vaginal prolapse repair using mesh. The authors were able to code 43 complication from 39 patients out of 107 (36.45\%). They stated that the classification system was found to be generally successful, but only needed to expand the coverage such as the need of reoperation, the duration of the impact of the complication, and severity of bleeding. In a small scaled retrospective study with 57 patients, Hammett et al. (16) drew attention to the rate of the resolution of symptoms after mesh removal. They showed that the complete resolution or improvement rate was $57.3 \%$ with the use of the IUGA/ICS classification system.

\section{Conclusion}

The IUGA/ICS complication classification system is one of a kind and the first universal classification coding system facilitating the standardized data accumulation and surgical audit specifically for vaginal prostheses. The system can be enriched and strengthened by covering urinary functional problems. Although gaining a prompt and deep insight into the CTS system seems difficult, the online calculator can accurately simplify classification. We believe that the complications' classification system should be increasingly used to achieve an objective and international agreement. This may allow to standardize documentation, leading to a more accurate assessment of complications and their severity.

Peer-review: Externally peer-reviewed.

Conflict of Interest: No conflict of interest is declared by the authors.

Financial Disclosure: The authors declared that this study received no financial support.

\section{References}

1. Haylen BT, Freeman RM, Swift SE, Cosson M, Davila GW, Deprest $\mathrm{J}$, et al. An international urogynecological association (IUGA)/ International continence society (ICS) joint terminology and classification of the complications related directly to the insertion of prostheses (meshes, implants, tapes) \& grafts in female pelvic floor surgery. Int Urogynecol J 2011; 22: 3-15.

2. Tunitsky E, Abbott S, Barber MD. Interrater reliability of the International Continence Society and international urogynecological association (ICS/IUGA) classification system for mesh-related complications. Am J Obstet Gynecol 2012; 206: 442.

3. Gowda M, Kit LC, Stuart Reynolds W, Wang L, Dmochowski RR, Kaufman MR. Interobserver variability when employing the IUGA/ ICS classification system for complications related to prostheses and grafts in female pelvic floor surgery. Int Urogynecol J 2013; 24: 1671-8.

4. Fusco F, Abdel-Fattah M, Chapple CR, Creta M, La Falce S, Waltregny $\mathrm{D}$, et al. Updated systematic review and meta-analysis of the comparative data on colposuspensions, pubovaginal slings, and midurethral tapes in the surgical treatment of female stress urinary incontinence. Eur Urol 2017; 72: 567-91. 
5. Rac G, Younger A, Clemens JQ, Kobashi K, Khan A, Nitti V, et al. Stress urinary incontinence surgery trends in academic female pelvic medicine and reconstructive surgery urology practice in the setting of the food and drug administration public health notifications. Neurourol Urodyn 2017; 36: 1155-60.

6. Ford AA, Rogerson L, Cody JD, Aluko P, Ogah JA. Mid-urethral sling operations for stress urinary incontinence in women. Cochrane Database Syst Rev 2017; 7: CD006375.

7. Gurol-Urganci I, Geary RS, Mamza JB, Duckett J, El-Hamamsy D, Dolan L, et al. Long-term rate of mesh sling removal following midurethral mesh sling insertion among women with stress urinary incontinence. JAMA 2018; 320: 1659-69.

8. Keltie K, Elneil S, Monga A, Patrick H, Powell J, Campbell B, et al. Complications following vaginal mesh procedures for stress urinary incontinence: an 8 year study of 92,246 women. Sci Rep 2017; 7: 12015.

9. Miklos JR, Chinthakanan O, Moore RD, Mitchell GK, Favors S, Karp DR, et al. The IUGA/ICS classification of synthetic mesh complications in female pelvic floor reconstructive surgery: a multicenter study. Int Urogynecol J 2016; 27: 933-8.

10. Dogan O, Kaya AE, Pulatoglu C, Basbug A, Yassa M. A randomized comparison of a single-incision needleless (Contasureneedleless ${ }^{\circledR}$ ) mini-sling versus an inside-out transobturator (Contasure-KIM ${ }^{\circledR}$ ) mid-urethral sling in women with stress urinary incontinence: 24-month follow-up results. Int Urogynecol J 2018; 29: 1387-95.

11. Dogan O, Basbug A, Kaya AE, Pulatoglu C, Yassa M. A randomized prospective comparison of the needleless mini-sling "hammock" and "U-shape" configurations for management of stress urinary incontinence: 18 month follow-up results. Arch Gynecol Obstet 2018; 297: 1483-93.

12. Skala C, Renezeder K, Albrich S, Puhl A, Laterza RM, Naumann G, et al. The IUGA/ICS classification of complications of prosthesis and graft insertion: a comparative experience in incontinence and prolapse surgery. Int Urogynecol J 2011; 22: 1429-35.

13. Haylen BT, Lee J, Maher C, Deprest J, Freeman R. Optimizing study design for interobserver reliability: IUGA-ICS classification of complications of prostheses and graft insertion. Int Urogynecol J 2014; 25: 751-4.

14. Batalden RP, Weinstein MM, Foust-Wright C, Alperin M, Wakamatsu MM, Pulliam SJ. Clinical application of IUGA/ICS classification system for mesh erosion. Neurourol Urodyn 2016; 35: 589-94.

15. Bontje HF, van de Pol G, van der Zaag-Loonen HJ, Spaans WA. Follow-up of mesh complications using the IUGA/ICS categorytime-site coding classification. Int Urogynecol J 2014; 25: 817-22.

16. Hammett J, Peters A, Trowbridge E, Hullfish K. Short-term surgical outcomes and characteristics of patients with mesh complications from pelvic organ prolapse and stress urinary incontinence surgery. Int Urogynecol J 2014; 25: 465-70. 


\section{Supplement}

\section{ICS/IUGA Protez-Greft Komplikasyon Sinıflandırılması* \\ https://www.ics.org/complication}

\section{KATEGORI}

1. Vajinal: Epitelyal ayrilma yok,

- Vajinal çıkıntılar (buruşma veya katlanma gibi), meş lifinin palpasyonu veya kontraksiyonu (büzüşmesi) dahil.

2. Vajinal: $\leq 1 \mathrm{~cm}$ dışarı çıkma,

3. Vajinal: $>1 \mathrm{~cm}$ dışarı çıkma (veya herhangi ekstrüzyon olması).

4. Üriner trakt:

- Herhangi bir kötüleşme veya perforasyon. Perforasyon, fistül ve taş (kalkül) dahil.

5. Rektum veya barsak:

- Herhangi bir kötüleşme veya perforasyon. Greft perforasyonu ve fistül dahil.

6. Deri ve/veya kas-iskelet:

- Akıntı, ağrı, şişkinlik (topaklaşma) veya sinüs traktı oluşumu.

7. Hastada kötüye gidiş:

- Hematom veya sistemik kötüleşme dahil.

\section{BÖLÜM (kategori 1)}

A. Anormal protez (meş veya greft),

- Klinik muayenede meşe dair herhangi bir anormallik.

B. Semptomatik,

- Örneğin; alışılmadık rahatsızlık hissi/ağrı; disparoni (partnerde de olabilir); kanama.

C. Enfeksiyon varlığı veya şüphesi,

D. Apse.

\section{BÖLÜM (kategori 2, 3)}
A. Asemptomatik,
B. Semptomatik,
C. Enfeksiyon,
D. Apse.

\section{BÖLÜM (kategori 4)}

A. Küçük intraoperatif defekt,

- Örneğin; mesane perforasyonu.

B. Alt üriner trakt,

- Diğer alt üriner trakt komplikasyonu veya üriner retansiyon.

C. Üretere veya üst üriner trakta ait.

\section{BÖLÜM (kategori 5)}

A. Küçük intraoperatif defekt,

- (Rektal veya bağırsak).

B. Rektal hasar veya kötüleşme,

C. Küçük veya büyük bağırsak hasarı veya kötüleşme,

D. Apse.

\section{BÖLÜM (kategori 6)}

A. Asemptomatik,

- Klinik muayenede anormal bulgu.

B. Semptomatik,

- Örneğin; akıntı, ağnı veya şişkinlik (topaklaşma).

C. Enfeksiyon,

- Örneğin; Sinüs traktı oluşumu.

D. Apse.

\section{BÖLÜM (kategori 7)}

A. Kanama,

- Hematom dahil.

B. Majör resüsitasyon veya yoğun bakım ihtiyacı,

C. Mortalite.

\section{AĞRI}

Sinıflandirılamayan;

A. Asemptomatik veya ağnı yok,

B. Uyarılma ile ağı,

- (Vajinal muayene esnasında).

C. Cinsel aktivite sırasında ağrı,

D. Fiziksel aktivite sırasında ağrı,

E. Spontan ağrı.

\section{SÜRE}

T1: İntraoperatif-48 saat,

T2: 48 saat- 2 ay,

T3: 2-12 ay,

T4: $>12$ ay.

\section{YER}

S1- Vajinal: Sütur hattı boyunca,

S2- Vajinal: Sütur hattı alanından farklı bölgede,

S3- Trokar geçiş hattında (batın içi hariç),

S4- Diğer deri veya kas-iskelet alanları,

S5- Batın içi. 


\section{NOTLAR}

1. Aynı hastada birden fazla farklı komplikasyonlar görülebilir. Aynı hastada erken ve geç komplikasyonlar görülebilir. Bütün komplikasyonlar belirtilmelidir. Komplikasyonlar tablosu uygulanan prosedüre spesifik olmalıdır.

2. Bir kçomplikasyona ait zaman içinde bir değişiklik görülürse en büyük final kategorisi not edilmelidir.

3. Üriner trakt enfeksiyonları ve fonksiyonel problemler (4B haricindeki) dahil edilmemiştir.

\section{TANIMLAR}

Çıkıntı: Yüzeyden dışarı uzanma (örneğin; epitelyal ayrılma olmadan buruşma veya katlanma sebebiyle).
Kontraksiyon: Büzüşme veya boyutta küçülme.

Eksposure: Açığa çıkması, görülebilir veya ulaşılabilir hale gelmesi (örneğin; meş ekstrüzyonu).

Ekstrusion: Bir vücut parçası veya doku boyunca parça halinde dışarı çıkması, yürümesi.

\section{Reference}

Haylen BT, Freeman RM, Swift SE, Cosson M, Davila GW, Deprest J, et al. An International Urogynecological Association (IUGA)/International Continence Society (ICS) joint terminology and classification of the complications related directly to the insertion of prostheses (meshes, implants, tapes) and grafts in female pelvic floor surgery. Neurourol Urodyn 2011; 30: 2-12. 